\title{
Гострі тромбоемболічні ускладнення у пацієнтів з хірургічною патологією органів черевної порожнини
}

\author{
YA. S. BEREZNYTSKYI, I. L. VERKHOLAZ, K. O. YAROSHENKO, S. L. MALYNOVSKYI
}

Dnipropetrovsk Medical Academy

\section{ACUTE THROMBOEMBOLIC COMPLICATIONS IN PATIENTS WITH SURGICAL PATHOLOGY OF ABDOMINAL CAVITY}

\begin{abstract}
Частота виникнення гострих тромбоемболічних ускладнень (ГТЕУ) щорічно збільшується та складає понад 100 випадків на 100000 населення. В останні роки ГТЕУ стали займати провідне місце серед післяопераційних за рахунок впровадження нових хірургічних технологій, удосконалення техніки операційних втручань, високого рівня сучасної анестезіології та інтенсивної терапії, які привели до зниження операційної летальності та зменшення виникнення специфічних післяопераційних ускладнень. Незважаючи на різноманіття запропонованих схем щодо призначення антикоагулянтів із метою профілактики виникнення ГТЕУ, кількість виникнення останніх викликає необхідність більш детального вивчення факторів ризику ГТЕУ та удосконалення існуючих схем профілактики й лікування цієї патології. Проведено статистичний ретроспективний аналіз результатів лікування пацієнтів із гострою хірургічною патологією органів черевної порожнини, які перебували на стаціонарному лікуванні в К3 “ШМКЛ” ДОР” у 20132015 рр. За результатами аналізу медичної документації: загальна кількість пацієнтів із ГТЕУ (ТЕЛА) - 72 (0,43 \%), кількість пацієнтів, яким діагноз було встановлено під час лікування, - 34 (47,2 \%), під час патологоанатомічної експертизи - 38 (52,8 \%); у 51 пацієнта ТЕЛА виявилась безпосередньою причиною смерті, 21 пацієнта вилікувано консервативними методами у відділенні інтенсивної терапії. У пацієнтів із невідкладною хірургічною патологією, особливо $з$ онкологічною патологією, необхідно визначати фактори ризику розвитку ГТЕУ, призначати профілактику або лікування останніх відповідно до затверджених стандартів (протоколів) надання медичної допомоги.

The incidence of acute thromboembolic complications (ATEC) is increasing annually and is equal to more than 100 cases per 100000 people. In recent years ATEC came to occupy a leading position among postoperative ones through the introduction of new surgical technologies, improvement of surgery techniques, high level of modern anesthetics and intensive care, which resulted in lower mortality and reduced occurrence of specific postoperative complications. Despite the variety of proposed schemes by application of anticoagulants to prevent ATEC occurrence, their number requires a more detailed study of risk factors of ATEC and improvement of existing schemes for prevention and treatment of this pathology. The statistical retrospective analysis of outcomes of patients with acute surgical pathology of abdominal organs who were hospitalized in 2013-2015 were performed. According to this analysis the total number of patients with ATEC is 72 (0.43 \%), the number of patients for whom the diagnosis was established during treatment is $34(47.2 \%)$, while pathoanatomical examination makes up 38 (52 $8 \%)$; PE in 51 patients proved to be the immediate cause of death, 21 patients cured with conservative methods in intensive care. In patients with urgent surgical pathology, especially cancer pathology, it is necessary to determine the risk factors, to appoint the prevention or treatment up to the standards (protocols) of medical care.
\end{abstract}

Постановка проблеми і аналіз останніх досліджень та публікацій. Частота виникнення гострих тромбоемболічних ускладнень (ГТЕУ) щорічно збільшується та складає понад 100 випадків на 100000 населення. За даними вітчизняних авторів, ГТЕУ охоплює 1,5 \% населення, більша частина якого перебуває в працездатному віці $[1,2]$.

Впровадження нових хірургічних технологій, удосконалення техніки операційних втручань, високий рівень сучасної анестезіології та інтенсивної терапії привели до зниження операційної ле- тальності та зменшення виникнення специфічних післяопераційних ускладнень. Таким чином, ГТЕУ стали займати провідне місце серед післяопераційних ускладнень. За даними багатьох патологоанатомічних досліджень, в 50-80 \% випадків тромбоемболія легеневої артерії (ТЕЛА) не визначається взагалі, та в ряді випадків встановлюється лише можливий діагноз. При цьому летальність при нелікованій ТЕЛА сягає 60-80 \%, тоді як при встановленому діагнозі та проведенні відповідного лікування до 10-30 \% [1, 3]. 
3 метою діагностики застосовується низка діагностичних критеріїв [4]:

- клінічні (серцево-судинні, легенево-плевральні, церебральні, абдомінальні);

- інструментальні (електрокардіографічні, рентгенологічні, доплерографічні, ангіографічні та ін.);

- лабораторні (визначення рівня D-димеру, тропоніну).

Незважаючи на різноманіття запропонованих схем із призначення антикоагулянтів з метою профілактики виникнення ТЕУ, кількість виникнення останніх викликає необхідність більш детального вивчення факторів ризику ТЕУ та вдосконалення існуючих схем профілактики й лікування цієї патології.

Мета роботи: 3 метою оцінки ефективності проведення профілактики та лікування ТЕУ провести кількісний аналіз результатів лікування пацієнтів із гострою хірургічною патологією органів черевної порожнини за частотою виниклих тромбоемболічних ускладнень (ТЕЛА).

Матеріали і методи. Проведено статистичний ретроспективний аналіз результатів лікування пацієнтів із гострою хірургічною патологією органів черевної порожнини, які перебували на стаціонарному лікуванні в КЗ “ШМКЛ” ДОР” у 20132015 pp.

Фактори ризику виникнення ГТЕУ (пацієнтзумовлені та операційно-зумовлені) оцінювали за загальновизнаними методиками [3, 5]. Профілактику та лікування ТЕУ проводили згідно зі стандартами організації та професійно орієнтованими протоколами надання медичної допомоги хворим із невідкладною хірургічною патологією органів живота [2, 4].

Оцінку результатів ефективності застосування антикоагулянтів проводили на підставі об’єктивних та суб’єктивних показників.

Результати досліджень та їх обговорення. Для адекватної оцінки факторів ризику, за даними медичної документації, окремо визначали загальні фактори (уроджені, набуті, змішані). За- гальна кількість хворих, які перебували на стаціонарному лікуванні в КЗ “ШМКЛ” ДОР” за 3 роки: 16 506, з них оперовано 8723 (52,8 \%), післяопераційна летальність - 295 пацієнтів (3,4 \%), загальна летальність - 600 пацієнтів (3,6 \%) (табл. 1).

За результатами аналізу медичної документації:

- загальна кількість пацієнтів із ТЕУ (ТЕЛА) - $72(0,43 \%)$;

- кількість пацієнтів, яким діагноз було встановлено під час лікування, - 34 (47,2 \%), під час патологоанатомічної експертизи - 38 (52,8 \%);

- у 51 пацієнта ТЕЛА виявилась безпосередньою причиною смерті, 21 пацієнта вилікувано консервативними методами у відділенні інтенсивної терапії.

За нозологіями пацієнти з ГТЕУ розподілились таким чином:

- пацієнти хірургічного профілю: 40, 3 них оперовані - 12, не оперовані - 28;

- урологічного профілю: 13, з них оперовані 4, не оперовані - 9;

- проктологічного профілю: 19, з них оперовані - 11, не оперовані - 8 .

Післяопераційна летальність, викликана безпосередньо ТЕЛА, склала 0,3 \% (27 пацієнтів).

Всім оперованим пацієнтам до операції проводили профілактику тромбозу залежно від визначеної групи ризику, а саме:

- низький ризик - рання активізація, еластична декомпресія нижніх кінцівок;

- помірний - рання активізація, еластична декомпресія нижніх кінцівок, антикоагулянтна профілактична терапія;

- високий - рання активізація, еластична декомпресія нижніх кінцівок, антикоагулянтна профілактична терапія (прямими антикоагулянтами в підвищених дозах) з переходом на непрямі та корекція реологічних розладів [4, 5].

Для профілактики та лікування пацієнтів були застосовані як нефракціонований гепарин, так і низькомолекулярні гепарини [5].

Пацієнти, які не були оперовані, отримували профілактичну терапію в 50 \% (тобто 36 пацієнтів) при наявності лабораторних (за даними систе-

Таблиця 1. Показники якості надання медичної допомоги пацієнтам із гострою хірургічною патологією органів черевної порожнини

\begin{tabular}{||l|c|c|c||}
\hline \multicolumn{1}{|c|}{ Показник } & 2013 р. & 2014 р. & 2015 р. \\
\hline Кількість пацієнтів, які госпіталізовані в стаціонар & 5348 & 5638 & 5520 \\
\hline Оперовані пацієнти & $3037(56,8 \%)$ & 2907 (51,6 \%) & $2779(50,3 \%)$ \\
\hline Післяопераційна летальність & $107(3,5 \%)$ & $80(2,8 \%)$ & $108(3,9 \%)$ \\
\hline Загальна летальність & $203(3,8 \%)$ & $189(3,4 \%)$ & $208(3,7 \%)$ \\
\hline \hline
\end{tabular}


ми гемостазу) та клінічних ознак гіперкоагуляції відповідно до вищезгаданої схеми.

Із 72 пацієнтів з ГТЕУ у 42 (58,3 \%) основним захворюванням стало занедбане онкологічне захворювання з віддаленими метастазами.

Висновки. 1. У пацієнтів із невідкладною хірургічною патологією органів черевної порожнини необхідно визначати фактори ризику розвитку гострих тромбоемболічних ускладнень та відповідно призначати профілактику або лікування

\section{СПИСОК ЛІТЕРАТУРИ}

1. Артеріальні, венозні тромбози та тромбоемболії. Профілактика та лікування : наукове видання / відп. за вип. В. Ю. Лішневська. - К. : ЗАТ “Віпол”, 2011. - 72 с.

2. Стандарти організації та професійно орієнтовані протоколи надання медичної допомоги хворим з невідкладною хірургічною патологією органів живота / ра ред. Я. С. Березницького, П. Д. Фоміна. - К., 2010. - 470 с.

3. Randomized trial of the effect of the low molecular weight heparin nadroparin on survival in patients with cancer / F. F. Door- останніх відповідно до затверджених стандартів (протоколів) надання медичної допомоги.

2. Пацієнтів з онкологічною патологією слід розцінювати як “потенційно небезпечних” за тромбоемболічними ускладненнями та призначати їм антикоагулянтну терапію (відповідно до стану системи гемостазу) нефракціонованим гепарином 3-6 разів на день або низькомолекулярними гепаринами у терапевтичній дозі щоденно в комплексі з фізичними методами профілактики ГТЕУ.

maal, M. Di Nisio, H. M. Otten [et al.] // J. Clin. Oncol. - 2011. Vol. 29(15). - P. 2071-2076.

4. A randomized phase II trial of apixaban for the prevention of thromboembolism in patients with metastatic cancer / M. N. Levine, C. Gu, H. A. Liebman [et al.] // J. Thromb. Haemost. - 2012. - Vol. 10(5). - P. 807-814.

5. Prophylactic anti-coagulation in cancer palliative care: a prospective randomised study / C. Weber, T. Merminod, F. R. Herrmann, G. B. Zulian // Support Care Cancer. - 2008. - Vol. (7). - P. 847-852. 